\title{
Bright Future with Nematicidal Phytochemicals
}

\section{Mohamed S Khalii*}

Central Agricultural Pesticides Laboratory, Agricultural Research Center, El-Sabaheya, Alexandria, Egypt

\begin{abstract}
The environmental pollution with chemical pesticides became a serious problem in pest control systems around the world. Chemical nematicides are part of the environmental problems, and in the same time, are the basic and the first defense line utilize against phytoparasitic nematodes. Thus it was necessary to search about alternative sources could be used in integrated nematode management programs. Using plant parts in pest management is one of the oldest options for the human such as, chrysanthemum spp, Derris elliptical and Ryania speciosa. Nowadays, various phytochemicals that extracted from different plant parts such as alkaloids, glycosides, limonoids, quassinoids and even phenolics became a new and/or promising tools to use as fungicides, bactericides and nematicides.
\end{abstract}

\section{Introduction}

No one can deny that phytonematodes became one of the most destructive pest around the world. The latest statistics in 2012 showed that plant parasitic nematodes cause damages estimated by $\$ 118$ billion [1].

Nematodes are aquatic animals which considered the most numerous Metazoa on the earth. They are divided into many classes such as free-living or parasites of plants and animals $[2,3]$. Phytonematodes are root feeders, which completing their life cycles in or on the root zone or even shoot zone in some cases. The most wide spread plant nematodes that parasitize crops are the root-knot nematodes which consist of more than 150 species. Among the root-knot nematodes, Meloidogyne javanica (Treub) Chitw., M. incognita (Kofoid and White) Chitw., M. arenaria (Neal) Chitw., and M. hapla Chitw., are of major agronomic importance, being responsible for 95\% of infestations [4] and responsible for at least $90 \%$ of all damage caused by nematodes [5]

Moreover, in a survey it was found that the root-knot nematodes are the most targeted group by $48 \%$ of nematicides that use in various crops [6]. At the same time, he found that in terms of global crop production, vegetables attract $38 \%$ of the nematicide market, followed by potato $(25 \%)$, banana $(9 \%)$, tobacco $(8 \%)$, sugar beet $(6 \%)$ and other crops (14\%). There are certain and various methods to control the plant parasitic nematode around the world. The most broad-spectrum method which the most farmers depend on is chemical control, next to biological control, resistant varieties, trap crops, crop rotation, cover crops, cultural control and soil solarization have been tested with different levels of successes [7,8]. Accordingly, several groups of researchers are attempting to maximize the role of bio-nematicides in managing phytonematodes because of certain advantages over synthetic products, such as: (i) contain novel compounds that plantparasitic nematodes are not yet able to resist; (ii) are less concentrated and thus less toxic than synthetic compounds; (iii) biodegrade relatively rapidly; and (iv) are derived from renewable sources $[9,10]$. The source of these bio-nematicides could be plants, bacteria, fungi, actynomycetes and / or any microorganism from the soil. Also, natural materials like chitin, Chitosan or even mushrooms. The newest bionematicides which used in the last years are avermectin group, name products and certain groups of microorganisms. Meanwhile, plants are very imported source for recent materials that could be used as bionematicides like phytochemicals. Therefore, it was necessary to throw a light on some of these phytochemicals.

\section{Piperamides}

Solanaceae: Piperamides is produced by certain species of piper genus, such as capsaicin which belong to Capsicum genus, (Capsicum frutescens, Mill.), has nematicidal properties [11,12]. Piperamids have been considered contact toxicant, repellent and antifeedant, as well as neurotoxins [13]. Very little data are available about the environmental fate of capsaicin, but initial assessment suggests that it will bind to sediments [14].

\section{Polyacetylenes and polythienyls}

Asteraceae: Marigold (Tagetes spp.) contains polyacetylenes and polythienyls that proved their nematicidal activity $[9,15]$. The first report about the resistance of marigolds verities to nematodes was by Goff [16], who recorded that French marigolds (T. Patula) and African marigolds ( $T$. Erecta) were the most types that suppressed the root-knot nematode infection during trials of 80 different ornamental annuals. The nematicidal performance of marigold depends on the usage way e.g., intercrop/cover crop/soil amendment, seeding rate, the marigold cultivar, the species or races of target nematodes, the temperature, or the age of marigold plant [17]. Incorporating marigolds in $M$. incognito infested cowpea or soybean fields has the potential to reduce the nematode populations and yields damages [18]. Marigold suppressed $M$. incognito efficiently when planted immediately following an $M$. incognita susceptible crop but did not enhance beneficial soil organism [19]. Furthermore, African marigold compost effectively reduced $M$. incognita infection in tomato [20 ] Moreover, the aqueous root extracts of marigold were applied against Meloidogyne sp.on tomato seedlings resulted in increased plant indices over the control treatment [21].

\section{Cyanogenic glycosides}

Euphorbiaceae: Cyanogenic glycosides are amino acid present in more than 2500 plant species, playing an important role in plant

*Corresponding author: Mohamed S Khalil, Central Agricultural Pesticides Laboratory, Agricultural Research Center, El-Sabaheya, Alexandria, Egypt, Tel: +2/01009297847; E-mail: melonema@gmail.com

Received November 09, 2013; Accepted November 11, 2013; Published January 06, 2014

Citation: Khalil MS (2014) Bright Future with Nematicidal Phytochemicals. Biol Med 6: e104. doi: 10.4172/0974-8369.1000e104

Copyright: @ 2014 Khalil MS. This is an open-access article distributed under the terms of the Creative Commons Attribution License, which permits unrestricted use, distribution, and reproduction in any medium, provided the original author and source are credited. 
defense against herbivores due to their bitter taste and release of toxic hydrogen cyanide. Cassava roots and leaves (Manihot esculenta) contain various quantities of cyanogenic glucosides and some little quantities of linamarin and lotoaustralin. When cells are damaged, enzymes hydrolyze these glucosides, releasing cyanide via cyanohydrin intermediates. Meanwhile, a liquid substance was found to release in cassava roots called Manipueira, this substance has been utilized for nematode control in Brazil [22,23].

Poaceae: Sudan grass (Sorghum sudanense) used as a green manure that release nematicidal compounds. Sudan grass contains glycoside dhurrin which can be hydrolyzed to yield cyanide. It was found that fractionated Sudan grass extracts effective against M. hapla [24].

\section{Terpenes}

Terpenes structures are consisting of isoprene units (C5), which may contain oxygen. Terpenoids are classified to hemi-terpenes (C5), monoterpenes (C10), sesquiterpenes (C15), diterpenes (C20), triterpenes (C30), and tetraterpenes (C40) [25]. Some pairs of terpenes have synergistic impact on $M$. incognita which cause paralysis, and those pairs are trans-anethole/geraniol, trans-anethole/eugenol, carvacrol/eugenol, and geraniol/carvacrol [26].

\section{a - Sesquiterpenoids}

Malvaceae: The first sesquiterpenoids discovered to be nematotoxic were the aldehydes hemigossypol and 6-methoxyhemigossypol, in addition the dimmers gossypol, and 6-methoxygossypol. These compounds are found to be associated with resistant varieties of cotton (Gossypium hirsutum) to M. incognita [27]. A crude terpenoid aldehyde extract from cotton inhibited the movement of $M$. incognita at $50 \mu \mathrm{g} /$ $\mathrm{ml}$, while gossypol did at $125 \mu \mathrm{g} / \mathrm{ml}$ [28].

Solanaceae: Rishitin is a sesquiterpenoid phytoalexin found in potato tuber discs (Solanum tuberosum), which infected with the potato rot nematode Ditylenchus dipsaci [29].

Pinaceae: Also, $\alpha$-humulene is a sesquiterpene which extracted from Pinus massoniana and found to be repellent to B. xylophilus that cause red ring in the heart -wood of pine [30].

\section{B - Diterpenoids}

Thymelaeaceae: Odoracin is a plant extract from roots of Daphne odora, which found toxic compound against Aphelenchoides besseyi, at $5.0 \mu \mathrm{g} / \mathrm{ml}$ [31]. This compound, is consisting of a diterpenoid (C20), benzoic acid as well as a fatty acid. Also, odoratrin is related substance which was isolated and recorded activity [32].

\section{Conclusion}

In this mini assay it was aimed to show the importance of some phytochemicals and try to make a small notes to those who work at pesticides industries fields and could extract and formulating phytochemicals alone or / and combined with pesticides.

\section{References}

1. Atkinson HJ, Lilley CJ, Urwin P E (2012) Strategies for transgenic nematode control in developed and developing world crops. Curr opin Biotechnol 23: 251-256.

2. Cobb NA (1915) Nematodes and their Relationships. Year book of the Department of Agriculture for 1914, Washington: 457-490.

3. De Ley P, Blaxter M (2002) Systematic position and phylogeny. In: LeeD.L. (ed.): The Biology of Nematodes. Taylor \& Francis, London: 1-30

4. Sasser JN, Eisenback JD, Carter CC, Triantaphyllou AC (1983) The international Meloidogyneproject its goals and accom-plishments. Ann. Rev. Phytopathol 21: 271-288.

5. Castagnone-Sereno $P(2002)$ Genetic variability in parthenogenetic root-knot nematodes, Meloidogyne spp., and their ability to overcome plant resistance genes. Nematology, 4: 605-608.

6. Haydock PPJ, Woods SR, Grove IG, Hare M (2006) Chemical contro of nematodes. In: Plant Nematology (Perry, RN. and MoenM. eds.), CAB International, Wallingford, UK, 392-410 PP.

7. Randhawa N, Sakhuja PK, Singh I (2001) Management of root-knot nematode Meloidogyne incognitain tomato with organ-ic amendments. Plant Dis. Res16: 274-276.

8. Sakhuja P, Jain RK (2001) Nematode diseases of vegetable crops and their management. In: "Diseases of Fruits and Vegetables and their Management" (T.S. Thind, ed.). Kaly-ani Pub., Ludhiana, India, 474 pp

9. Chitwood DJ (2002) Phytochemical based strategies for nematode control Annu. Rev. Phytopathol., 40, 221-249

10. Ferraz S ,Grassi de Freitas L (2004) Use of antagonistic plants and natura products. In: Chen, Z.X., Chen, S.Y and Dickson, D.W. (Eds) Nematology Advances and Perspectives - Volume 2, Nematode Management and Utilization. CAB International, Wallingford, UK, pp. 931-977

11. Djian-Caporalin, Fazari A, Arguel MJ, Vernie T,Vande Casteele C, et al (2007) Root-knot nematode (Meloidogyne spp.) Meresistance genes in pepper (Capsicum annuum L.) are clustered on the P9 chromosome.Theor. Appl. Genet 114: 473-86.

12. Neves WS, de Freitas LG, CoutinhoMM, Dallemole-Giaretta R, Fabry CFS, et al. (2009) Nematicidal activity of extracts of red hot chili pepper, mustard and garlic on Meloidogyne javanica in green house. Summa Phytopathol 35:255-261.

13. Scott IM, Jensen HR, PHilogene BJR, Arnason JT (2008) A review of Piper spp. (Piperaceae) Phytochemistry and insecticidal activity and mode of action. Phytochem. Rev1: 65-75.

14. Thomas KV, Brooks S (2010) The environmental fate and effects of antifouling paint biocides. Biofouling 26: 73-88.

15. Wat CK, Prasad SK, Graham EA, Partington S, Arnason T,et al. (1981) Photosensitization of invertebrates by natural polyacetylenes. Biochem. Syst. Ecol9: 59-62.

16. Goff CC (1936) Relative susceptibility of some annual ornamentals to root-knot Univ. Fla. Agric. Exp. Sta. Bull.291. 15 pp.

17. Hooks CRR, Wang KH, Ploeg A, McSorley R (2010) Using marigold (Tagetes spp.) as a cover crop to protect crops from plant-parasitic nematodes. Appl. Soil Ecol 46: 307-320.

18. Adekunle OK (2011) Amendment of soil with African marigold and sunn hemp for management of Meloidogyne incognita in selected legumes. Crop Prot 30: 1392-395.

19. Marahatta SP,Wang KH, Sipes BS,Hooks CRR (2010) Strip-tilled cover cropping for managing nematodes, soil mesoarthro-pods, and weeds in a bitter melon agroecosystem.J. Nematol 42: 111-119.

20. Pandey R, Kalra A (2010) Inhibitory effects of vermicompost produced from agro-waste of medicinal and aromatic plants on egg hatching in Meloidogyne incognita (Kofoid and White) Chitwood. Curr. Sci 98: 833-835.

21. Olabiyi TI (2008) Pathogenicity study and nematoxic properties of some plan extracts on the root-knot nematode pest of tomato, Lycopersicon esculentum( $L$. Mill.Plant Pathol 7: 45-49.

22. Ponte JJ, Cavada BS, Silveira-Filho J (1996) Teste com lectina no controle de Meloidogyne incognita em tomateiro. Fitopatol. Bras. 21: 489-91

23. Sena ES, Ponte JJ (1982) A manipueira no controle da meloidoginosa da cenoura. Rev. Soc. Bras. Nematol. 6: 95-98.

24. Widmer TL, Abawi GS (2000) Mech-anism of suppression of Meloidogyne haplaand its damage by a green manure of Sudan grass. Plant Dis $84: 562-68$.

25. Aharoni A, Jongsma MA, Bouwmeester HJ (2005) Volatile science? Metabolic engineering of terpenoids in plants. Trends Plant Sci 10: 594-602.

26. Ntalli NG, Ferrari F, Giannakou IO, Menkissoglu-Spiroudi U (2011) Synergistic and antagonistic interactions of terpenes against Meloidogyne incognita and 
nematicidal activity of essential oils from 7 plants indigenous in Greece. Pest Manag. Sci 67: 341-51.

27. Veech JA, Mc Clure MA (1977) Terpenoid aldehydes in cotton roots susceptible and resistant to the root-knot nematode, Meloidogyne incognita. J. Nematol 9: 225-29.

28. Veech Jab (1979) Histochemical local-ization and nematotoxicity of terpenoid aldehydes in cotton. J Nematol 11: 240-46

29. Zinovieva SV, Chalova LI (1987) Phy-toalexins of potato and their role in the resistance to stem nematodes. Hel-minthologia 24: 303-9.
30. Suga T, Ohta S, Munesada K, Ide N, Kurokawa M, et al. (1993) Endogenous pine wood nematicidal substance in pines,Pinus massioniana, $P$. strobusand $P$. palustris. Phytochemistry 33: 1395- 1401.

31. Kogiso S, Wada K, Munakata K (1976) Odoracin, a nematicidal constituent from Daphne odora. Agric. Biol. Chem 40: 2119-20.

32. Munakata K (1983) Nematocidal natural products. InNatural Products for Innovative Pest Management, ed. DL White-head, WS Bowers 299-310. Oxford Pergamon. 